\title{
HUBUNGAN PERAWATAN INFUS DENGAN KEJADIAN FLEBITIS PADA PASIEN RAWAT INAP DI RUANG MAWAR RSUD Dr. HARJONO KABUPATEN PONOROGO.
}

\author{
Detik Andriani \\ Progam Studi Si Ilmu Keperawatan STIKES Buana Husada Ponorogo \\ Email : detikandriani88@gmail.com
}

\begin{abstract}
ABSTRAK
Pemasangan infus sebagai salah satu tindakan invasif memerlukan keterampilan yang cukup saat melakukan pemasangannya. Flebitis adalah peradangan pada dinding pembuluh darah balik atau vena. Tujuan penelitian ini untuk mengetahui hubungan perawatan infus dengan kejadian flebitis pada pasien rawat inap di ruang Mawar RSUD Dr. Harjono Kabupaten Ponorogo. Desain penelitian studi korelasional. Jenis penelitian ini kuantitatif dengan metode observasional dan wawancara. Sampel peneliatian 10 perawat yang ada di ruang Mawar RSUD Dr. Harjono Ponorogo dan 30 pasien yang ada di ruang Mawar. Teknik sampling menggunakan accidental sampling dengan Uji Chi Square $\mathrm{p}$ value $=0,01(\mathrm{p}<0,05)$. Data hasil penelitian yaitu Pasien yang mengalami flebitis sebanyak 12 responden (40\%) dan tidak mengalami flebitis 18 responden (60\%) dikarenakan perawatan infus yang kurang sebesar 17 responden (57\%), sebanyak 13 responden $(43 \%)$ dalam kategori baik dan responden dengan kategori baik sekali sebanyak 0 responden (0\%) di Ruang Mawar RSUD Dr. Harjono Ponorogo. Berdasarkan hasil penelitian ini dapat dijadikan bahan pertimbangan dalam menentukan kebijakan berupa pengadaan acuan atau pedoman perawatan infus RSUD Dr. Harjono Ponorogo.
\end{abstract}

Kata kunci :Perawatan Infus, Kejadian Flebitis

\section{PENDAHULUAN}

Pemasangan infus sebagai salah satu tindakan invasif yang memerlukan keterampilan cukup pada saat melakukan pemasangannya. Akibat prosedur pemasangan yang kurang tepat, seperti posisi yang salah, kegagalan saat menginsersi vena,serta ketidakstabilan dalam memasang fiksasi,dan kurang memperhatikan Standar Operasional Prosedur (SOP) pemasangan infus, serta kurang memperhatikan teknik sterilisasi hal tersebut dapat menimbulkan bahaya bagi pasien. Selain itu, pemberian terapi infus juga dapat menimbulkan komplikasi lokal yang sering terjad iadalah flebitis (Hankins, et al., 2001;
Richardson \& Bruso, 1993 dalam Gabriel, 2008; Alexander, et al., 2010).

Angka kejadian flebitis yang direkomendasikan oleh infusion Nurses Society (INS) sebesar 5\% atau kurang. Sementara dari hasil study literature yang ditemukan angka kejadian flebitis berkisar antara 20-80\% (Campbell, 1998). Dari hasil penelitian lainnya menemukan angka kejadian flebitis di tiga Rumah Sakit yang berada di Jakarta sangat tinggi sekitar 33,8\% (Gayatri dan Handiyani, 2008). Akhir tahun 2005 Menteri Kesehatan telah menegaskan untuk mengembangkan program patient safety di seluruh rumah sakit dan fasilitas kesehatan lainnya tujuannya untuk menciptakan budaya patient safety 


\section{Jurnal Delima Harapan 2020}

dan meningkatkan akuntabilitasi rumah sakit (Hayati 2012). Dari hasil studi pendahuluan yang dilaksanakan bulan Desember 2019 pada pasien rawat inap di ruang Mawar RSUD Dr. Harjono Kabupaten Ponorogo oleh peneliti didapatkan data dari perawat menunjukkan bahwa jumlah pasien Rawat inap yang dilakukan pemasangan infus 3 minggu terakhir sebanyak 30 pasien dan yang mengalami flebitis sebanyak 12 (30\%). Dari 12 pasien yang mengalami kejadian flebitis tersebut tidak mendapatkan perawatan infus sesuai standart yang ada.

The Infusion Nursing of Practice yaitu dampak dari kejadian flebitis dapat menjadi bahaya, karena akan terjadi bekuan darah atau trombo flebitis dan bisa menyebabkan emboli, hal ini dapat menimbulkan kerusakan permanen pada vena. Kejadian flebitis meningkat sesuai dengan lamanya pemasangan infus, dari kejadian tersebut dapat mengakibatkan pasien menjalani perawatan yang lebih lama sehingga dapat meningkatkan angka kejadian flebitis pada pasien. Solusi yang bisa dilakukan dalam pencegahan angka kejadian flebitis bisa kita lakukan perawatan infus secara benar di rumah sakit. Ini sangat berpengaruh terhadap kejadian flebitis antara lain memakai sarung tangan, membasahi plaster dengan alkohol dan buka balutan dengan menggunakan pinset, membersikan bekas plaster, memberikan kompres hangat pada bagian yang mengalami pembengkakan, jika terjadi nyeri atau bengkak pada area pemasangan infus maka perawat harus melepas infus dan mengganti infus agar pasien tidak mengalami infeksi pada area pemasangan infus tersebut, perawat memeriksa tempat penusukan IV setiap hari, perawat mengganti seluruh infus set sedikitnya setiap 3 hari, membersihkan daerah tusukan dan sekitarnya dengan NaCL, mengolesi tempat tusukan dengan iodin, dan menutup dengan kasa steril dengan rapi .
Tujuan penelitian ini adalah diantaranya adalah:

1. Mengidentifikasi Perawatan Infus Di Ruang Mawar RSUD Dr. Harjono

Kabupaten Ponorogo

2. Mengidentifikasi Kejadian Flebitis Di Ruang Mawar RSUD Dr. Harjono Kabupaten Ponorogo

3. Menganalisa Hubungan Perawatan Infus Dengan Kejadian Flebitis Pada Pasien Rawat Inap Di Ruang Mawar RSUD Dr. Harjono Kabupaten Ponorogo.

\section{METODE PENELITIAN}

Dalam penelitian ini desain penelitian yang digunakan adalah korelasional analitik yaitu penelitian yang bertujuan untuk mengetahui hubungan atau pengaruh dari variabel satu dengan variabel lainnya. Tujuan penelitian ini adalah untuk mengetahui hubungan perawatan infus dengan kejadia flebitis pada pasien rawat inap di Ruang Mawar RSUD Dr.Harjono Kabupaten Ponorogo. Populasi dalam penelitian ini adalah 60 pasien yang terpasang infus dan 12 perawat di Ruang Mawar RSUD Dr. Harjono Kabupaten Ponorogo pada bulan Mei-Juli 2019. Sampel dalam penelitian ini adalah 30 pasien yang terpasang infus dan 10 perawat yang ada di Ruang Mawar RSUD Dr.Harjono Kabupaten Ponorogo. Instrumen yang digunakan daam dalam pengumpulan data hubungan perawatan infus dengan kejadian flebitis pada pasien rawat inap di Ruang Mawar RSUD Dr.Harjono Kabupaten Ponorogo berupa lembar Observasi dan Wawancara. Untuk menentukan hubungan perawatan infus dengan kejadian flebitis pada pasien rawat inap menggunakan teknik uji chi square. Dengan alpha 0,05 dan tingkat pengelolaan data dioah dengan menggunakan sistem kepercayaan $95 \%$. Signifikan atau komputerisasi dengan bantuan software bermakna jika $\mathrm{p}$ Value $<0,05$. 


\section{Jurnal Delima Harapan 2020}

\section{HASIL PENELITIAN}

1. Identifikasi Perawatan Infus pada Pasien Rawat Inap di Ruang Mawar RSUD Dr. Harjono Ponorogo.

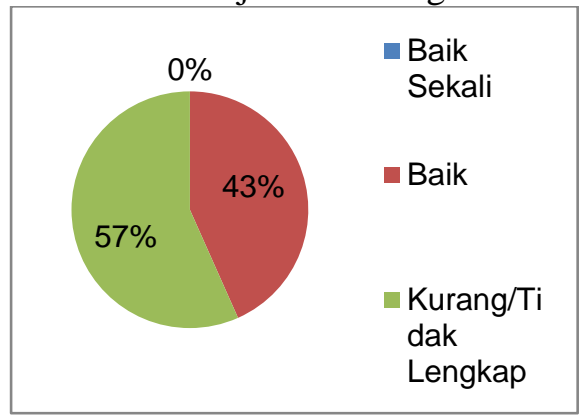

Berdasarkan gambar diatas didapatkan hasil perawatan infus yang dilakukan oleh perawat sebanyak 17 responden (57\%) kurang/ tidak lengkap, sebanyak 13 responden (43\%) masuk dalam kategori baik dan responden dengan kategori baik sekali yaitu tidak ada atau $0 \%$.

2. Identifikasi kejadian flebitis pada Pasien Rawat Inap di Ruang Mawar RSUD Dr. Harjono Ponorogo.

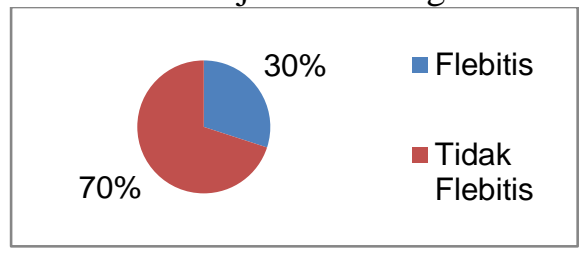

Berdasarkan gambar diatas didapatkan hasil bahwa pasien mengalami febitis yaitu 12 pasien (30\%)sedangkan yang tidak mengalami flebitis sebanyak 18 pasien $(70 \%)$.

3. Hubungan Perawatan Infus dengan Kejadian Flebitis pada Pasien Rawat Inap di Ruang Mawar RSUD Dr. Harjono Kabupaten Ponorogo.

\begin{tabular}{|c|c|c|c|c|c|}
\hline & \multicolumn{4}{|c|}{ Kejadian Flebitis } & tidak sama dalam pelaksanaannya. \\
\hline & & & $\begin{array}{l}\text { Tidak } \\
\text { Flebitis }\end{array}$ & Flebitis & Total Perawat melakukan tindakan \\
\hline \multirow[t]{4}{*}{$\begin{array}{l}\text { Pe- } \\
\text { rawatan } \\
\text { Infus }\end{array}$} & $\begin{array}{l}\text { Baik } \\
\text { Sekali }\end{array}$ & $\mathrm{N}$ & 0 & 0 & $\begin{array}{l}\text { perawatan infus apabila keluarga } \\
\text { pasien meminta diganti balutan pada } \\
\text { infus, hal ini dikarenakan beban kerja }\end{array}$ \\
\hline & & $\%$ of & $0 \%$ & $0 \%$ & yang tinggi dan kondisi ruang yang \\
\hline & & Total & & & kurang kondusif. Pelaksanaan \\
\hline & Baik & $\begin{array}{l}\mathrm{N} \\
\% \text { of }\end{array}$ & $\begin{array}{ll}12 \\
40,0 \%\end{array}$ & $\begin{array}{ll}1 \\
3,0 \%\end{array}$ & $\frac{13}{43,0 \%}$ tindakan keperawatan perlu adanya \\
\hline
\end{tabular}

\section{Corelations}

\begin{tabular}{|r|r|}
\hline $\begin{array}{c}\text { Perawatan } \\
\text { Infus }\end{array}$ & $\begin{array}{c}\text { Kejadian } \\
\text { Flebitis }\end{array}$ \\
\hline 1,000 &,$- 577^{* *}$ \\
30 &, 001 \\
,$- 577^{* *}$ & 30 \\
, 001 & 1,000 \\
30 & 30 \\
\hline
\end{tabular}

Dari hasil uji chi square diatas diperoleh nilai signifikan $\mathrm{p}$ value 0,01 (karena $\mathrm{p}$ value $<0,05$ ) maka $\mathrm{H} 0$ ditolak dan H1 diterima yang artinya "ada hubungan perawatan infus dengan kejadian flebitis pada pasien rawat inap di Ruang Mawar RSUD Dr.Harjono Kabupaten Ponorogo

\section{PEMBAHASAN}

1. Perawatan Infus pada Pasien Rawat Inap di Ruang Mawar RSUD Dr. Harjono Ponorogo

Berdasarkan hasil penelitian perawatan infus pada pasien rawat inap di Ruang Mawar RSUD Dr. Harjono Ponorogo didapatkan hasil penelitian bahwa perawatan infus baik sekali $0(0 \%)$, baik sebanyak 13 responden (43\%) dan kurang lengkap sebanyak 17 responden (57\%). Hal ini dikarenakan perawat dalam melakukan tindakan perawatan infus tidak sesuai dengan pengetahuan mereka dan masing-masing perawa dak sama dalam pelaksanaannya.

\begin{tabular}{|c|c|c|c|c|c|}
\hline & \multicolumn{3}{|l|}{ 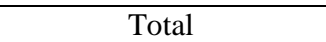 } & \multirow[b]{2}{*}{11} & \multirow[b]{2}{*}{17} \\
\hline & $\begin{array}{l}\text { Kuran } \\
\text { g }\end{array}$ & $\mathrm{N}$ & 6 & & \\
\hline & & $\%$ of & $20,0 \%$ & $37,0 \%$ & $57,0 \%$ \\
\hline & & Total & & & \\
\hline Total & & $\mathrm{N}$ & $60,0 \%$ & $40,0 \%$ & $100 \%$ \\
\hline
\end{tabular}


sebuah pedoman atau standar sebagai acuan sehingga dalam melaksanakan suatu tindakan dapat dipertanggung jawabkan secara ilmiah sehingga jika suatu tindakan dilakukan tidak dengan acuan atau suatu pedoan maka dapat dikatakan tidak dapat dipertanggung jawabkan secara ilmiah dan dokumentasi atau secara administrasi.

Perawatan infus merupakan tindakan yang diakukan perawat kepada pasien yang telah mendapatkan pemasangan infus sesuai prosedur guna menghindari hal-hal yang tidak diinginkan untuk mencegah terjadinya infeksi atau cara untuk mencegah masuknya mikroorganisme pada vasikuler sehingga tidak menimbulkan terjadinya infeksi saat terpasang infus. Sementara itu perawatan infus pada tempat penusukan juga harus dilakukan antara lain: setiap hari, perlu dilakukan penutupan balutan steril tempat masuk kanula IV periver, balutan harus diganti jika balutan menjadi kotor, basah, atau lepas dan perawat mengganti seluruh infus set setidaknya 3 hari sekali.

Hasil penelitian ini didukung penelitian terdahulu dengan judul gambaran pelaksanaan prosedur perawatan infus dengan kejadian flebitis di RSUD Kajen Kabupaten Pekalongan yang menyatakan bahwa $88,6 \%$ perawat yang sudah diobservasi melaksanakan prosedur perawatan infus dengan benar dan kejadian flebitis $11,9 \%$. Kejadian flebitis ini dipengaruhi oleh faktor lain seperti usia pasien . Berdasarkan hasil penelitian ini dapat di jadikan sebagai acuan atau pedoan untuk membuat suatu kebijakan tentang perawatan infus sehingga tidak terjadi malpraktek dan dapat dipertanggung jawabkan serta dipertanggung gugatkan tindakan perawatan infus yang dilakukan oleh perawat

2. Kejadian Flebitis pada Pasien Rawat Inap di Ruang Mawar RSUD Dr. Harjono Ponorogo

Hasil dari penelitian yang dilaukan di Ruang Mawar RSUD Dr. Harjono Ponorogo menunjukan bahwa pasien yang mengalami flebitis sebanyak 12 pasien $(30 \%)$ yang dapat diketahui dengan cara mengobservasi lokasi tempat pemasangan infus dengan melihat adanya tanda dan gejala flebitis yang meliputi nyeri sepanjang kanul, kemerahan, pembengkakan. Berdasarkan hasil diatas dapat dikategorikan angka flebitis di ruang rawat inap tinggi hal ini dikarenakan bangsal penyakit dalam perawatan infus dilakukan tidak sesuai dengan teori yang seharusnya.

Flebitis merupakan daerah bengkak, kemerahan, panas, serta nyeri pada kulit sekitar tempat kateter intravaskuler dipasang (kulit bagian luar. Hasil penelitian ini didukung oleh penelitian terdahulu yang berjudul kejadian flebitis di Rumah Sakit Umum Daerah Majalaya dengan hasil dari 90 responden yang diobservasi $32,2 \%$ yaitu mengalami flebitis dan $67,8 \%$ tidak mengalami flebitis dan dari hasil uji Chi Square dan Coeffisien Contingensi didapatkan hasil peneitian tersebut didapatkan hasil bahwa ada hubungan yang bermakna anatara faktor resiko pemasangan infus dengan $\mathrm{p}$ sebesar 0,031 , faktor usia dengan $\mathrm{p}$ value 0,007 dengan kejadian flebitis.

3. Hubungan Perawatan Infus dengan Kejadian Flebitis pada Pasien Rawat Inap di Ruang Mawar RSUD Dr. Harjono Kabupaten Ponorogo.

Berdasarkan hasil penelitian dapat diketahui bahwa terdapat hubungan antara perawatan infus dengan kejadian flebitis pada pasien rawat 
inap di Ruang Mawar RSUD Dr. Harjono Ponorogo dengan hasil wawancara yaitu petugas melakukan tindakan perawatan infus kurang kepada pasien sehingga terjadi kejadian flebitis dan data hasil penelitian Pasien yang mendapatkan perawatan infus dengan baik sekali dan tidak mengalami flebitis $(0 \%)$, mendapatkan perawatan infus baik sekali dan mengalami flebitis $(0 \%)$, mendapatkan perawatan infus baik dan tidak mengalami flebitis sebanyak 12 pasien (40\%), mendapatkan perawatan infus baik dan mengalami flebitis sebanyak 1 pasien (3,0\%), mendapatkan perawatan infus dengan kurang lengkap dan tidak mengalami flebitis sebanyak 6 pasien $(20,0 \%)$, mendapatkan kurang lengkap dan mengalami flebitis sebanyak 11 pasien $(37,0 \%)$. Data tersebut dapat menggambarkan bahwa pasien yang mendapatkan perawatan infus kurang baik mempunyai resiko lebih besar mengalami kejadian flebitis.

Hasil penelitian berdasarkan uji Chi Square diperoleh $\mathrm{p}$ value $=0,01$ $(\mathrm{p}<0,05)$, dengan demikian hipotesis penelitian diterima dapat disimpulkan bahwa ada hubungan yang signifikan antara perawatan infus dengan kejadian flebtis pada pasien rawat inap di Ruang Mawar RSUD Dr. Harjono Ponorogo.

Hasil pada penelitian ini terdapat beberapa kasus dimana responden yang dilakukan perawatan infus kurang baik tetapi tidak terjadi flebitis. Berdasarkan data penelitian didapatkan data bahwa responden dirawat dengan tidak terlalu banyak mendapatkan terapi injeksi sehingga pasien dirawat tidak terlalu lama atau $>4$ hari sehingga menurunkan resiko terjadinya flebitis. Berdasarkan wawancara yang telah dilakukan kepada 12 petugas di ruang Mawar RSUD Dr. Harjono Ponorogo bahwa sebagian pasien yang tidak mengalami flebitis tidak dilakukan perawatan infus dengan baik seperti mengganti transparan dresing, tidak mendesinfektan area penusukan infus dengan alkohol swab bila tidak terjadi flebitis.

Berdasarkan hasil penelitian melalui teknik observasi dan wawancara angka kejadian flebitis masih cukup banyak dan tindakan perawatan infus masih minim sekali dilakukan karena beban kerja yang banyak dan jumlah pasien yang banyak sehingga petugas kurang dalam melakukan tindakan perawatan infus sesuai dengan acuan atau pedoman yang telah ditetapkan, hal ini dapat dikatakan bahwa kejadian flebitis pada pasien rawat inap di ruang mawar RSUD Dr. Harjono Ponorogo tidak hanya dipengaruhi oleh perawatan infus saja, akan tetapi juga dipengaruhi oleh terapi obat atau osmolaritas cairan yang diberikan.

\section{KESIMPULAN}

1. Perawatan infus yang dilakukan pada pasien yang terpasang infus di ruang Mawar RSUD Dr. Harjono Ponorogo dari 30 responden sebanyak 17 responden (57\%) mendapatkan perawatan infus dengan kategori kurang.

2. Kejadian flebitis pada pasien yang terpasang infus di ruang Mawar RSUD Dr. Harjono Ponorogo dari 30 responden yaitu 12 responden (30\%) mengalami flebitis.

3. Hasil analisa penelitian menggunakan teknik wawancara kepada petugas dan uji Chi Square didapatkan $\mathrm{p}$ value $=0,01$ $(\mathrm{p}<0,05)$ dapat disimpulkan bahwa ada hubungan yang signifikan antara perawatan infus dengan kejadian flebitis pada pasien rawat inap di Ruang Mawar RSUD Dr. Harjono Kabupaten Ponorogo. 


\section{SARAN}

1. RSUD Dr. Harjono Ponorogo

Hasil dari penelitian ini dapat dijadikan sebagai bahan pertimbangan dalam melakukan dan menentukan kebijakan pembuatan acuan perawatan infus. Hendaknya tim PPI(Pencegahan dan Pengendalian Infeksi) perawat yang ada di rumah sakit lebih berperan aktif dalam menganggulangi atau mengurangi kejadian HAI's.

2. Prodi Keperawatan STIKES Buana Husada Ponorogo.

Dari penelitian ini dapat digunakan sebagai salah satu sumber bacaan atau pedoman yang dapat menambah informasi dan wawasan tentang keperawatan managemen khususnya dan sebagai bahan referensi tentang perawatan infus dan kejadian flebitis bagi Mahasiswa/i STIKES Buana Husada Ponorogo.

3. Peneliti selanjutnya.

Peneliti selanjutnya dapat melanjutkan dan mengembangkan penelitian serupa dengan menggunakan variabel dependen lain yang berhubungan dengan faktor-faktor yang menyebabkan terjadinya suatu kejadian flebitis.

\section{DAFTAR PUSTAKA}

Abdul, R. 2016. Hubungan perawatan infus dengan kejadian flebitis pada pasien rawat inap di bangsal penyakit dalam dan syaraf Rumah Sakit Nur Hidayah Bantul. Skripsi FIK Universitas Alma Ata. Yogyakarta.

Amirullah. 2017. Evaluasi teknik pemasangan infus dan insiden phlebitis di RSUD H. A. Sulthan Daeng Radja Bulukumba. Tesis
FIK Universitas Hasanudin.

Makassar.

Ayu, N. 2017. Gambaran faktorfaktor yang mempengaruhi kepatuhan perawat dalam tindakan perawatan infus di ruang rawat inap RSUD Ungaran. Skripsi Departemen Ilmu Keperawatan Universitas Diponegoro. Semarang.

Christian, M. 2014. Hubungan lamanya pemasangan infus (intravena) dengan kejadian flebitis pada pasien di irina f blu RSUP Prod. Dr. R. D. Kanidou Manado, ejounal Keperawatan, Vol. 2, No. 1.

Dede, D. 2016. Hubungan jenis cairan dan lokasi pemasangan infus dengan kejadian flebitis pada pasien rawat inap di RSU Pancaran Kasih Gmim Manado, ejournal Keperawatan, Vol. 4, No. 1.

Esti, 2011. Buku Ajar Fundamental Keperawatan. Jakarta:Kedokteran EGC.

Imram, 2016. Pengaruh Lama Pemasangan Infus Dengan Kejadian Flebitis Pada Pasien Rawat Inap Di Bangsal Penyakit Dalam Dan Syaraf Rumah Sakit Nur Hidayah Bantul, Journal Ners And Midwifery Indonesia, Vol.4, No.2 : 90-94

Noviar,2017. Hubungan Kepatuhan Perawat Igd Dalam Melaksanakan Sop Pemasangan Infus Dengan Kejadian Infeksi Nosokomial (Flebitis) Di Rsud Kotabaru Kalimantan Selatan, Nursing News, Vol.2, No.2

Nunung, H. 2018. Hubungan kepatuhan SPO pemasangan infus dengan kejadin flebitis di RSUD 
A. Wahab Sjahranie Samarinda Tahun 2015, Jurnal Ilmu Kesehatan, Vol. 6.

Nursalam, 2015, Manajemen Keperawatan : Aplikasi dalam Praktik Keperawatan Profesional Edisi 5. Jakarta : Salemba Medika.

Saryono, 2011. Catatan Kuliah Kebutuhan Dasar Manusia $(K D M)$. Yogyakarta:

Muha Medika. Sujono, 2012, Standard Operating Proedure Dalam Praktik Klinik Keperawatan Dasar. Yogyakarta: Pustaka Pelajar.

Sumijatun, 2017. Konsep Dasar Menuju Keperawatan Profesional. Jakarta: CV. Trans Info Media.

Supryianto. 2008. Hubungan antara tingkat pendidikam perawat dengan kepatuhan penerapan prosedur tetap pemasangan infus di ruang rawat inap RSDM Surakarta. Skripsi FIK Universitas Muhamammadiyah. Surakarta.

Wayunah, 2013. Pengetahuan Perawat Tentang Terapi Infus Memengaruhi Kejadian Flebitis Dan Kenyamanan Pasien,Keperawatan Indonesia, Vol.16, No.2 :128-137 